\title{
Assessing the Impact of Microfinance and Small Loans Scheme (Masloc) as a Poverty Reduction Strategy in the Sunyani Municipality
}

\author{
Victoria Adu Kyerewaa ${ }^{1} \quad$ Peter Saben-Fosu ${ }^{2 *}$ \\ 1.Department of Economics, Faculty of Social Sciences, College of Humanities and Social Sciences, Kwame \\ Nkrumah University of Science and Technology, PMB, Kumasi, Ghana \\ 2.Department of Economics, Faculty of Social Sciences, College of Humanities and Social Sciences, Kwame \\ Nkrumah University of Science and Technology, PMB, Kumasi, Ghana
}

\begin{abstract}
The study assesses the effects of MASLOC as poverty reduction strategy in the Sunyani Municipality. A case study design was adopted with a descriptive survey as the main study design and approach. Structured questionnaire was employed as the main data collection instruments to collect primary data from 112 MASLOC beneficiaries in the Sunyani Municipality of the Bono East Region. Both purposive and simple random sampling techniques were used to select the sample size. The study outcome shows that the level of poverty among beneficiaries before becoming MASLOC beneficiaries in the Sunyani Municipality was high and could hardly afford basic needs of life. However, after experiencing MASLOC, their status improve and could afford basic needs such as medical bills, school fees and other educational needs and even start and expand businesses and improve product and customer services. Again, the study discovered challenges to the MASLOC beneficiaries: high interest rate on loans, lack of collateral security to secure loans, stringent credit conditions, administrative costs associated with processing loans, biasness of MASLOC staff, among others. Finally, significant positive effects on improving the living standards of beneficiaries were concluded. The study recommended management of MASLOC to collaboratively work with the National Commission for Civic Education and other media organizations to develop and implement an advocacy and sensitization programme. Also, a good system that makes it very easy and fair for poor people to access credit from the scheme should be created. The Government of Ghana (GoG) should implement policies that make it favourable for poor people to access credit facilities from MASLOC and other Financial Institutions that grant credit to poor people.
\end{abstract}

Keywords: Microfinance, Small Loans Scheme, Poverty, Poverty Reduction, Small Business

DOI: $10.7176 / \mathrm{JESD} / 13-2-04$

Publication date: January $31^{\text {st }} 2022$

\section{Introduction}

The subject of poverty has gained much prominence and has become the main developmental agenda of many national and international organizations all over the world due to its devastating effects on social and economic welfare on the human race especially for developing nations. Poverty has become the number one social canker in the world because many people in societies lack resources for their basic needs, (World Bank, 2011; Mwinga, 2012). The World Bank (2021) defined poverty as a situation when a person lives or survives on less than US $\$ 1.90$ per day and most of them are living in developing world.

The United Nation's (UN) in an attempt to find solutions to the poverty menace have come out with various developmental agendas such as the Millennium Development Goals and the Sustainable Development Goals (MDGs) which have resulted in an increase of microfinance which caught the attention of many governments, NGOs, aid donors as an effective tool for poverty reduction. Microfinance has become one of the widely known strategies for reducing poverty in the world, (Arp, Ardisa \& Ardisa, 2016).

In Ghana, successive governments over the years have implemented various macro and micro economic policy interventions, strategies and programmes geared towards reducing poverty. To address the poverty gap, the Government of Ghana implemented several interventions ranging from livelihood enhancement programs to support program for enterprise development and the setting up of microfinance institutions under the Ghana Poverty Reduction Strategy (GPRS) II to provide loans to the marginalized productive poor as a tool for reducing poverty and creating jobs (BOG, 2015). One of such key programme was the Microfinance and Small Loan Centre (MASLOC).

The Government of Ghana (GoG) established the MASLOC in 2006 by as a microfinance apex body responsible for implementing microfinance programmes aimed at reducing poverty, creating jobs and wealth across the country, under the Growth and Poverty Reduction Strategy (GPRS II). MASLOC's facilities are principally targeted at the marginalized productive poor who fall mostly within the micro small and medium enterprises sector, (Debrah, 2013). The scheme was grounded on the $\mathrm{MC}^{2}$ Model which is a theory that has the objective of given microcredit to the poor to enable them to improve on their small business activities and reduce 
their poverty levels, (Obwanga, 2012). MASLOC provide loans such as micro-credit or group loans, small or individual loans and wholesale lending to its beneficiaries for a short period not exceeding twelve (12) months within which they have to be repaid with interest. The conditions necessary for obtaining a MASLOC loan includes being between the age of 18 and 65 years and of sound mind; have an on-going business venture or project; been a member group between 5 and 25 among others.

The Sunyani Municipality which is a peri-urban has agriculture as its major source of livelihood for the people. The extent and intensity of poverty in the Sunyani Municipality had been on the increase that one can plainly see it from the daily lives of the people. For instance, Antwi (2015) through an empirical study observed that a typical indigenous family in the Sunyani Municipality could hardly afford three square meals and educational needs due to financial challenges. The author also established high illiteracy rate, high population growth rate, poor water and insanitary conditions, malnutrition and child labour as other indicators of poverty in the Sunyani Municipality.

The central objective of this study was to evaluate the effects of MASLOC as poverty reduction strategy in the Sunyani Municipality. Specifically, this objective is addressed by examining the response to the following questions:

- What was the level of poverty of beneficiaries before becoming MASLOC beneficiaries in the Sunyani Municipality?

- What are the benefits beneficiaries have gained from joining the MASLOC scheme in the Sunyani Municipality?

- What are the challenges MASLOC beneficiaries faces in accessing micro credit facilities in the Sunyani Municipality?

- What are the impacts of MASLOC facilities on improving the living standards of beneficiaries in the Sunyani Municipality?

The following two hypotheses were also set to support the study objectives:

$\mathrm{H}_{10}$ : There is no significant relationship between MASLOC credit facilities and growth in income

$\mathrm{H}_{1 \mathrm{a}}$ : There is a significant relationship between MASLOC credit facilities and growth in income

$\mathrm{H}_{20}$ : There is no significant relationship between MASLOC credit facilities and increase in consumption expenditure.

$\mathrm{H}_{2 \mathrm{a}}$ : There is a significant relationship between MASLOC credit facilities and increase in consumption expenditure.

The study was delimited both in context and geographical location. In context, the study was limited to the theme and sub-theme of poverty and microfinance. It also included other relevant literature related to the subject matter of poverty. Geographically, the study was limited to only microfinance in the Sunyani Municipality.

This study was organized into five chapters. Chapter one introduces the research study. The second chapter focuses on the review of materials and related literature which encompasses relevant concepts, frameworks and theories as well as empirical researches. Chapter three is the research methods and analysis where population, sample and sampling techniques, research instruments and procedure, study variables and model specifications were discussed. The fourth chapter presents results and discussions as well as summary of conclusions and recommendations of the study end in the fifth chapter.

\section{Review of Related Literature}

This chapter encapsulates theoretical, conceptual and empirical frameworks which highlight the relationship between the study variables and present also presents practical evidences of similar works previously done by scholars.

\subsection{Review of Relevant Concepts and Empirical Studies}

2.1.1 The Concepts of Poverty and Microfinance

According to Imtiaz, et al (2014), poverty is a vibrant subject which has a lot of dimensions with respect to time and region and this makes it difficult to define since it has a collection of diverse meanings based on where it is use, (Jaha and Sika-Bright, 2015). That is, there is no generalized definition of the concept of poverty. Nevertheless, a lot of scholars have attempted to define the concept of poverty. Yaro (2013) stated that poverty is the deficiency to resources that are needed for live. This shows that a deficiency of access to resources such as food, income, shelter, clothing, health, education, political processes among other physical resources becomes an obstacle to the social and economic improvement of an individual.

Dzisi and Obeng (2013) defined microfinance as encompassing the provision of financial services and the management of small amounts of money through a range of products and a system of intermediary functions that are targeted at low income clients. This means that microfinance is meant to provide financial support to entrepreneurs and small business owners who are less financially endowed and are likely not to get financial support from conventional banks due to lack of collateral security.

Rajper, Ghumro and Mangi (2018), asserts that microfinance is a tool use to increase the living standard of low income people by providing them access to financial services. This means that microfinance through its role 
of financial provision (i.e. savings, credit, insurance and remittances) help to create wealth, maintain living standards and reduce poverty.

Several studies have been conducted to prove the social and economic importance and contribution of microfinance towards poverty reduction (Qureshi, et al, 2012; Oduro-Ofori, et al, 2014; Garikipati, 2017). According to Kasali, et al, (2015), the objective of microfinance is to provide credit to people who do not have access to credit from bank. The goal of microfinance is to improve the socio-economic state of low income generator, (Abiola and Salami, 2011). Microfinance is therefore an effective instrument for poverty alleviation and suggests improvement in labour productivity; leading to increase household incomes. In Ghana, Debrah, (2013) discovered that microfinance improved standard of living through the provision of credit.

However, many years after the endorsement and introduction of microfinance, poverty still remains persistently high especially in third world developing countries and is still the most difficult development issue facing the international community today, (Omideyi, 2012).

2.1.2 Relationship between Microfinance and Poverty Reduction

Olumuyiwa and Oluwatosin (2012) conducted a study into the impact of MFIs on standard of living of hairdresser in Oshodi-Isolo Local Government of Lagos State, Nigeria. Specifically, the study examines how MFIs have influence the business of hairdressers and also examine the effect of MFIs on asset acquisition and savings of hairdressers in that LGA. The study population includes 120 registered hairdressers. The structured questionnaire was used to gather primary data and analyzed by the Spearman's correlation analysis. The study findings show that there is a significant relationship between MFIs efforts and standard of living of hairdressers. This finding was confirmed by Idowu, et al (2011) who also established that MFIs has significant effect in improving the standard of living of hairdressers in Ogbomoso in Nigeria.

Chirkos (2014) conducted a study on effect of MFIs on poverty alleviation of the poor people in Ethiopia. The study employed questionnaires as the main data collection tool. The sample size of the study was 150 . The study outcome shows that almost all the clients reported an increase in their incomes which has improved their standard of living, have sent their children to school; have been able to pay for their medical bills and can feed their families, can cope with future crises using their savings, have been empowered economically and their positions in the family as well as in the society.

In Ghana, Dzisi and Obeng (2013), examine the impact of microfinance on the socio-economic lives of women entrepreneurs in Ghana. The study selected the Koforidua Municipality as its study area and all women entrepreneurs who have accessed MFIs' loans in the municipality form the study population. A multi-method approach was used to select the sample size for data collection and analysis and with simple random sampling technique, eight hundred and forty (840) women beneficiaries of microfinance loans were surveyed; and interviews conducted with 35 of them. The overall results suggest that women's enterprises have expanded while their socioeconomic status has improved tremendously after taking the loans.

2.1.3 Challenges facing Beneficiaries in Accessing Micro Credit

Numerous empirical studies have shown that poor people faces a number of challenges when getting credit facilities from MFIs. A research conducted by Olumuyiwa \& Oluwatosin, (2012) revealed that high interest rate is a major challenge women face when accessing loans from MFIs.

Again, Abiola \& Salami, (2011) found that factors that hinder poor people accessibility to credit facilities include insufficient collateral, lack of management skills, difficult availability measures, strict credit arrangements and cultural prejudice. Similarly, Adjei (2010) also observed that factors such as low levels of education and inadequate training on loan, poor environmental factors, inflation, political uncertainty and instability in the market are some of the challenges that hinder poor people from accessing credit facilities from MFIs. Chirkos, (2014) noticed that poor borrowers encounter challenges such as high transaction costs, lack of collateral, and lack of credit history.

\subsection{Review of Theoretical Literature}

The effect of microfinance on poverty alleviation is grounded by several theories and considering the socioeconomic, cultural and political aspects of understanding microfinance as instrument for alleviating poverty in Ghana, the study purposely selected the theories of Grameen Bank Model, $\mathrm{MC}^{2}$ Model, Base of the Pyramid Approach and Village Banking Model of FINCA. These theories have been identified to have significant relationship between microfinance and poverty alleviation, (Nyakambi, 2014; Kyale, 2013; Obwanga, 2012; Okibo, 2014).

\subsubsection{Grameen Bank (GB) Model}

This Model was propounded by the Grameen Bank and Muhammad Yunus in Bangladesh in 1983 with the aim of giving micro-credits to the poor. The GB Model is based on the principle of group lending. This approach involves organizing poor people in smaller groups of 4 to 8 member to serve as collateral security to be able to meet the requirement of orthodox banks who demand huge collateral before giving loans to poor people. According to Nyakambi, (2014) the GB model has helped to reversed the high indemnity requirements by orthodox banks and 
settled on a structure centered on shared trust, responsibility, and association. The orthodox structure does not consider the poor, women and illiterates but rather creates a boundary between the between poor and the rich, (Nyakambi, 2014). The objective of this model is to create opportunities to enable poor people to grow their businesses thereby ending poverty. Studies have shown that the GB model help in improving the well-being of partaking families and improved family's ability to maintain their gains over time.

2.2.2 Village Banking Model (VBM)

The VBM was founded by the Foundation for International Community Assistance (FINCA) who applied the model in its effort to create financially-sustainable solidarity groups. The VBM model was originally propounded in the 1980s by John Hatch in Bolivia. According to the original model, the village banking model instituted by the FINCA works with groups of 30-60 members, usually all women. Kyale (2013) explained that as soon as the village bank is inaugurated, it receives its first loan from the implementing agency (the local headquarters of FINCA or its affiliate) for on-lending to the individual members of the village bank. The supporting agency expends 1 to 3 months in setting up each bank, establishing the voting of organization group and preparing its participants, as well as evolving the rules and regulations to administer the model. Loans are repaid on a weekly basis in equivalent repayments of principal and interest over a four-month period. These payments are collected at consistent gatherings and repay the entire loan principal plus interest to the implementing agency at the end of the $16^{\text {th }}$ week. The funds go back and forth between the executing organization and the village bank. If the village bank reimburses in full, it is eligible for a second loan. If the village bank is incapable to pay the quantity outstanding, the executing agency stops further credit until repayment is finished, (Kyale, 2013).

2.2.3 The $\mathrm{MC}^{2}$ Model

This theory was developed by Paul Fokam based on the Einstein's formula which is victory over poverty if the means $(\mathrm{M})$ and the competences $(\mathrm{C})$ of the community $(\mathrm{C})$ are combined. It has the objective of giving microcredit to the poor to enable them to improve on their small business activities. According to Obwanga, (2012) the theory functions on the basis that microcredit serves as the main solution to the ending poverty and it is operationalized on the premises that through microcredit, poor peoples' business will improve and advance in the society.

2.2.4 Base of the Pyramid Approach (BoP)

This theory was propounded by Prahalad and Hammond in the UK in the year 2002 and it postulates that poor people form majority of the world's population and they do business in the informal economy. The theory was developed on the premises that the greater the value created for those living at the BoP, the greater the value created for the venture. Indeed, BoP ventures are expected to generate acceptable economic and societal returns to the organization investing in the venture and the local community in which they operate.

\subsection{Conceptual Framework}

This study adopts the conceptual model propounded by Okibo (2014) which evaluates the connection between availability and access to credit facilities from MFIs and poverty reduction among poor people. The model postulates that there is a positive relationship between credit facilities from MFIs and poverty reduction. In the study, the dependent variables constitute income improvement and economic sustainability whiles the independent variable includes all credit facilities from MFIs. Microfinance was considered as the intervening variable.

Access to credit is seen to be important and this is served by MASLOC to provide credit for poor entrepreneurs. Again, MASLOC has an objective to provide credit and financial products to make life comfortable for poor people. This framework is displayed in figure 1 below. Based on this conceptual framework, the following hypotheses were stated:

$\mathrm{H}_{1}$ : There is no significant relationship between MASLOC credit facilities and improvement in standard of living. $\mathrm{H}_{2}$ : There is no significant relationship between MASLOC credit facilities and increase in beneficiary's household incomes. 


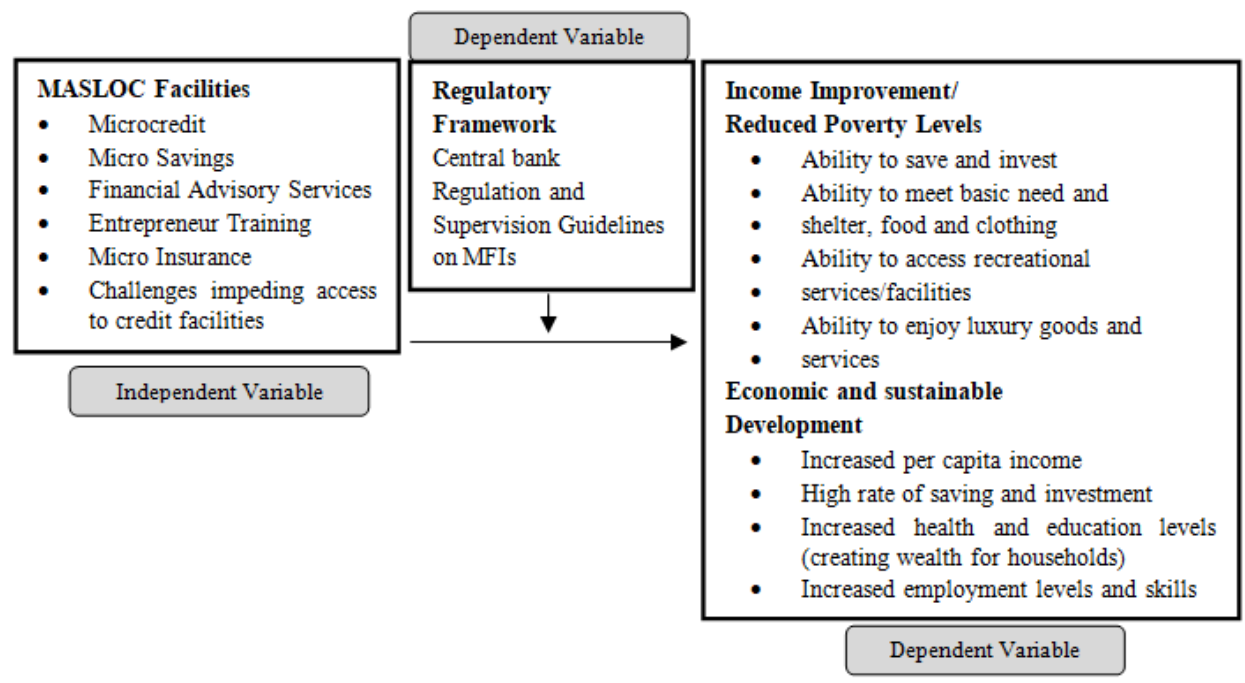

Figure 1. Conceptual framework adopted from Okibo, 2014

\section{Materials, Research Method and Analysis}

This section gives a brief description of the study area and then elaborates on the various techniques employ in collecting and analyzing the data.

\subsection{Research Design}

This study adopts a case study design and it focuses on MASLOC to describe the behavior or the effects of microfinance on poverty reduction of the group in the Sunyani Municipality. The choice of the study enabled the researcher to conduct a systematic enquiry into an event or a set of related events which aims to describe and explain the phenomenon of interest.

\subsection{Population, Sample and Sampling Techniques}

The target population includes all beneficiaries of MASLOC in the Sunyani Municipality. Stratified and simple random sampling techniques were adopted to sample from the population. The target population was categorized into their occupational sectors such as Farming (Food Crop \& Poultry Production), Fish mongering, Microenterprise, Vocations and SME/Agro-Marketing. A total sample of 120 comprising of both male and females MASLOC beneficiaries in the Sunyani Municipality were proportionately and randomly selected from the occupational sectors using the lottery method. A total of 120 copies of the questionnaire were distributed and 112 were received, representing $93.33 \%$.

\subsection{Data, Research Instruments and procedure}

Secondary data was gathered from review reports by the Microfinance Institutions (MFIs), publications of the Central Bank, the Ghana Statistical Service Department and including review of journals, articles, magazines, publications, among others to gather information from previous works related to this study. The primary data was obtained from the administration of questionnaires and interview (face to face) from both officials and beneficiaries of MASLOC. The study adopted an open-ended paper questionnaire as its core research instrument to solicit primary data from respondents in the Sunyani Municipality. Explanations and clarifications were given to respondents, where necessary, to elicit the needed information for the study.

\subsection{Study Variables: Dependent, Independent and Control Variables}

The dependent variable for the study was Income which was measured by the level of income (improving/not improving) earned by beneficiaries of MASLOC in the Sunyani Municipality.

The independent variables included all MASLOC services such as Micro Loans/Credit, Financial Advisory Services, Savings, Training on Bookkeeping and Micro insurance. These variables were measured by dummy variables; for instance if beneficiaries have received Micro Loans/Credit $=1$; otherwise $=0$; if beneficiaries have received Financial Advisory Services $=1$; otherwise $=0$; if beneficiaries have been able to made Savings on business enterprise from 2013-2020; and if beneficiaries have received Training on Bookkeeping (Replica variable $=1$; otherwise $=0$ ).

The control variables included Regulation and Supervision of MFIs by BoG and GHAMFIN and the Operational Guidelines on MASLOC. Table 1 below shows the summary of the various variables under study. 
Table 1. Description of Study Variables

\begin{tabular}{|c|c|c|c|}
\hline Variable & Definition & Measurement & $\begin{array}{l}\text { Expected } \\
\text { Sign }\end{array}$ \\
\hline \multirow{4}{*}{ Dependent } & Income & Growth in income & + Positive \\
\hline & & Ability to access health and education & + Positive \\
\hline & & Increase in consumption expenditure & + Positive \\
\hline & & $\begin{array}{l}\text { Acquisition \& expansion of business } \\
\text { assets }\end{array}$ & + Positive \\
\hline \multirow{3}{*}{ Independent } & Microcredit & Type of MASLOC Credit facilities & + Positive \\
\hline & $\begin{array}{l}\text { Financial Advisory Services } \\
\text { (Entrepreneurship training) }\end{array}$ & Type of Financial Advisory Services & + Positive \\
\hline & Micro Savings & Ability to save and invest & + Positive \\
\hline \multirow[t]{2}{*}{ Control } & $\begin{array}{l}\text { Regulation and Supervision by BoG } \\
\text { and GHAMFIN, Operational }\end{array}$ & GHAMFIN Regulations & + Positive \\
\hline & Guidelines on MASLOC & MASLOC Operational Guidelines & \\
\hline
\end{tabular}

3.5 Model Specification, Data Processing and Analysis

Both descriptive and inferential statistics were employed. A multivariate regression analysis was conducted to test the relationship between the dependent and independent variables and also to test the research hypothesis.

The study adopted multiple linear regression model which has the basic form;

$\mathrm{Y}=\beta_{0}+\beta_{1} \mathrm{X}_{1}+\beta_{2} \mathrm{X}_{2}+\beta_{3} \mathrm{X}_{3}+\beta_{4} \mathrm{X}_{4}+\varepsilon$ (Basic Model)

Where;

The independent variables included Micro Credit, Financial Advisory Services, Entrepreneur Training, and Micro Savings. The dependent variable was Income Improvement/Reduced Poverty Levels

$\mathrm{Y}=$ Income, measured by total income earned by beneficiaries of MASLOC in the Sunyani Municipality. It is also measured by beneficiaries' ability to meet basic need (shelter, food and clothing), ability to access health and education, ability to access recreational services.

$\beta_{0}=$ Constant term

$\beta=1 \ldots .4$, elasticity of the dependent to the independent variable. Thus, measure the variability of the dependent variable (Income) to a unit change in the independent variables.

$\mathrm{X}_{1}=$ Micro-Credit measured by the type of MASLOC loans and credit facilities

$\mathrm{X}_{2}=$ Financial Advisory Services

$\mathrm{X}_{3}=$ Micro Savings measured by beneficiary's ability to save and invest

$\mathrm{X}_{4}=$ Entrepreneurship Training

$\varepsilon=$ is the error term to capture unexplained variations in the model and which is assumed to be normally distributed with mean zero and constant variance.

The above model is represented below:

Income $=\beta_{0}+\beta_{1}$ Micro-Credits $+\beta_{2}$ Financial Advisory Services $+\beta_{3}$ Savings $+\beta_{4}$ Entrepreneur Training $+\varepsilon$

\section{Results and Discussions}

Results from the study are discussed and presented in this section.

\subsection{Demographic Information of Respondents}

The demographic information of the respondents has been captured in Table 2 defined below. 
Table 2. Demographic Information of Respondents

\begin{tabular}{|c|c|c|c|}
\hline $\begin{array}{l}\text { Demographic } \\
\text { Characteristics }\end{array}$ & Response & Frequency & Percentage \\
\hline \multirow[t]{3}{*}{ Gender } & Male & 54 & 48.00 \\
\hline & Female & 58 & 52.00 \\
\hline & Total & 112 & 100 \\
\hline \multirow[t]{6}{*}{ Educational Level } & Response & Frequency & Percentage \\
\hline & BECE & 30 & 27.00 \\
\hline & WASSCE/SSCE & 51 & 46.00 \\
\hline & Diploma & 24 & 21.00 \\
\hline & Undergraduate & 7 & 6.00 \\
\hline & Total & 112 & 100 \\
\hline \multirow[t]{7}{*}{ Age Distribution } & Response & Frequency & Percentage \\
\hline & 18-24 years & 13 & 12.00 \\
\hline & $26-34$ years & 30 & 27.00 \\
\hline & $35-44$ years & 35 & 31.00 \\
\hline & $45-54$ years & 21 & 19.00 \\
\hline & Above 55 & 12 & 11.00 \\
\hline & Total & 112 & 100 \\
\hline \multirow[t]{7}{*}{ Occupation } & Response & Frequency & Percentage \\
\hline & $\begin{array}{l}\text { Farming (Food Crop \& Poultry } \\
\text { Prod.) }\end{array}$ & 39 & 35.00 \\
\hline & Fish mongering & 6 & 5.00 \\
\hline & Microenterprise & 28 & 25.00 \\
\hline & Vocations & 23 & 21 \\
\hline & SME/Agro-Marketing & 16 & 14 \\
\hline & Total & 112 & 100 \\
\hline \multirow[t]{6}{*}{ Marital Status } & Response & Frequency & Percentage \\
\hline & Single & 29 & 26.00 \\
\hline & Married & 41 & 37.00 \\
\hline & Divorced & 16 & 14.00 \\
\hline & Window & 26 & 23.00 \\
\hline & Total & 112 & 100 \\
\hline \multirow[t]{5}{*}{ Religion } & Response & Frequency & Percentage \\
\hline & Christian & 63 & 56.0 \\
\hline & Muslim & 40 & 36.0 \\
\hline & None of the Above & 9 & 8.00 \\
\hline & Total & 112 & 100 \\
\hline
\end{tabular}

Source: Field Survey, 2020

There is a fair distribution of the sample size in terms of gender of beneficiaries of MASLOC scheme in the Sunyani Municipality, with $52.0 \%$ of the respondents as females while $48 \%$ are males, from Table 4.1 . Additionally, majority of the respondents have attained a minimum level of education and therefore understood and appreciated the questions and reliably responded. $46.0 \%$ of the respondents have WASSCE/SSCE as their highest educational qualifications followed by BECE (27\%), Diploma (21\%) and undergraduate degree (6\%).

Also, majority $(70 \%)$ of the respondents are in their mid-age which is from the age of 18 years to 44 years with only $30 \%$ above the age of 44 years. This signifies some level of maturity and as such fair responses were provided to the questions asked, making the research results dependable.

On marital status, $37.0 \%$ of the respondents are married whereas $26 \%$ and $23 \%$ of the respondents are singles and widowed, respectively. Only $14 \%$ of the respondents are divorced. This is an indication that most of the beneficiaries of MASLOC are people who are married or have married before therefore, have some sense of responsibility. Also, the distribution of religion is fairly represented with Christians (56\%) forming the majority followed by Muslims (36\%).

4.3 Level of Poverty among Beneficiaries before Becoming MASLOC beneficiaries in the Sunyani Municipality One of the specific objectives of the study is to determine the level of poverty among beneficiaries before becoming beneficiaries MASLOC in the Sunyani Municipality. The primary data obtained from the survey on this objective have been collated, analyzed and presented in Table 3 . 
Table 3. Occupational Status of respondents before and after becoming MASLOC Beneficiary

\begin{tabular}{lllll}
\hline Occupational Status & Yes & $\mathbf{\%}$ & No & \% \\
\hline Had no job/business before becoming MASLOC Beneficiary & 85 & 76 & 27 & 24 \\
Had job/business after becoming MASLOC Beneficiary & 94 & 84 & 18 & 16 \\
\hline
\end{tabular}

Source: Field Survey, 2020

It is observed that 85 respondents representing $76 \%$ of total respondents had no job/business before becoming MASLOC beneficiaries. However, 94 respondents representing $84 \%$ obtained job or new business after joining the MASLOC scheme. This suggests that most of the beneficiaries were living in poverty since they lack access to resources that are needed to achieve an adequate standard of living but the situation changed for the better when they joined the MASLOC scheme, alleviating the devastating effect of poverty and improving the social-economic development. This situation affects the living conditions of poor people as opined by Canagarajah \& Pörtner (2013).

Table 4. Income level of respondents before and after becoming MASLOC Beneficiary

\begin{tabular}{lllll}
\hline Income level below GHc302.10 per month & Yes & $\mathbf{\%}$ & No & $\mathbf{\%}$ \\
\hline Before becoming MASLOC Beneficiary & 80 & 71 & 32 & 29 \\
After becoming MASLOC Beneficiary & 13 & 12 & 99 & 88 \\
\hline
\end{tabular}

\section{Source: Field Survey, 2020}

Majority (80 representing 71.0\%) of the respondents had their income levels below GHc302.10 per month before becoming MASLOC Beneficiary. After joining the MASLOC scheme, 99\% had their income level increased to beyond GHc302.10 per month. This outcome suggests that the income levels of the MASLOC beneficiaries in the Sunyani Municipality have improved way above the World Bank standard classification of poverty which is $\$ 1.9$ per day equivalent to GHc302.10 per month. The MASLOC scheme therefore serves as an important intervention to alleviating the rising incidence of poverty in the Sunyani Municipality.

Table 5. Improvement in quality of products and services before and after becoming MASLOC Beneficiary

\begin{tabular}{lllll}
\hline Improvement in quality of products and services & Yes & $\mathbf{\%}$ & No & $\%$ \\
\hline Before becoming MASLOC Beneficiary & 34 & 30 & 78 & 70 \\
After becoming MASLOC Beneficiary & 77 & 69 & 35 & 31 \\
\hline
\end{tabular}

Source: Field Survey, 2020

Also, 78 representing $70 \%$ of the respondents agreed that there was little or no improvement in the quality of their products and services before becoming MASLOC beneficiaries. However, after joining the Scheme, 77 representing $69 \%$ of the respondent experienced improved quality of their product and services This demonstrates the positive impact the Scheme has had on the businesses of the beneficiaries through enhanced product and services quality, and this asserts to the findings of Chirkos (2014).

Table 6. Expansion of business before and after becoming MASLOC Beneficiary

\begin{tabular}{lllll}
\hline Expansion of my business & Yes & $\mathbf{\%}$ & No & $\mathbf{\%}$ \\
\hline Before becoming MASLOC Beneficiary & 17 & 15 & 95 & 85 \\
After becoming MASLOC Beneficiary & 102 & 91 & 10 & 9 \\
\hline
\end{tabular}

Source: Field Survey, 2020

Similarly, from Table 6 , it can be observed that 95 representing $85 \%$ of the respondents rarely expand their business before becoming MASLOC beneficiary. Nevertheless, 102 representing 91\% of the respondents experienced business expansion after benefiting from MASLOC. Irrefutably, most of the current beneficiaries of MASLOC in the Sunyani Municipality hardly expanded their business until they joined MASLOC where beneficiaries either added new product or services lines, entered new markets or opened new branches.

Table 7. Ability to save money before and after becoming MASLOC Beneficiary

\begin{tabular}{lllll}
\hline Ability to save money & Yes & $\mathbf{\%}$ & No & $\mathbf{\%}$ \\
\hline Before becoming MASLOC Beneficiary & 32 & 29 & 80 & 71 \\
After becoming MASLOC Beneficiary & 85 & 76 & 27 & 24 \\
\hline
\end{tabular}

Source: Field Survey, 2020

From Table 7, 80 respondents representing 71\% of respondents reported of their inability to save money before joining the Scheme but after becoming MASLOC beneficiary, $76 \%$ of the respondents reported of their ability to save funds. The improved ability to save money positively impacts the standard of living of beneficiaries of MASLOC in the Sunyani Municipality, as they can and will be able to afford their basic needs. This is in line with Olumuyiwa and Oluwatosin (2012) who noticed that microfinance have an impact on the savings of hairdressers in Oshodi-Isolo Local Government of Lagos State of Nigeria. 


\subsection{Benefits gained by beneficiaries of MASLOC in the Sunyani Municipality}

Table 8 . Benefits gained by beneficiaries of MASLOC

\begin{tabular}{lll}
\hline Benefits gained by beneficiaries of MASLOC & Yes (\%) & No (\%) \\
\hline $\begin{array}{l}\text { Have you been able to start up and or expand your business after joining the } \\
\text { MASLOC scheme }\end{array}$ & $99(88)$ & $13(12)$ \\
$\begin{array}{l}\text { Have you been able to improve the quality of my business products and services } \\
\text { after joining the MASLOC scheme }\end{array}$ & $77(69)$ & $35(31)$ \\
$\begin{array}{l}\text { Have your income status been improved after joining the MASLOC scheme } \\
\text { Have you been able to pay for my children school fees and other educational needs } \\
\text { after joining the MASLOC scheme }\end{array}$ & $85(73)$ & $30(27)$ \\
$\begin{array}{l}\text { Have you been able to feed and clothed your family after joining the MASLOC } \\
\text { scheme }\end{array}$ & $75(67)$ & $37(33)$ \\
\hline
\end{tabular}

Source: Field Survey, 2020

Out of 112 respondents, majority ( $88 \%$ ) of respondents have been able to start or expand their businesses as a benefit from MASLOC in the Sunyani Municipality agreeing to the work of Dzisi and Obeng (2013), who also discovered that microfinance activities in Ghana have help women to expand their enterprises which have led to an improvement in their socio-economic status.

Again, most of the respondents (69\%) of the respondents have benefitted from improved product and services while $31 \%$ have no impact on the quality of their products and services. The study also discovered that 82 representing $73 \%$ of the respondents have improved income as one of the gains in joining the Scheme while $27 \%$ have not experienced any increase in income.

Furthermore, whiles majority (76\%) of respondents answered they have been able to pay for their children's school fees and other educational needs after joining the MASLOC scheme, $24 \%$ of respondents still struggle with their educational expenses of their wards. The study also shows that whiles $16.3 \%$ of the respondents are in disagreement to the statement that "have been able to feed and clothed your family after joining the MASLOC scheme", majority (67\%) of the respondents answered Yes to the very question.

These findings confirm the study of Chirkos (2014) who noticed that almost all the clients of Debratabor and Estie branches of ACSI which is a microfinance company in Ethiopia had an increase in their incomes which has improved their standard of living. As their incomes increase, they have been able to send their children to school; have been able to pay for their medical bills and can feed their families, can cope with future crises using their savings and have been empowered economically in the family as well as in the society.

\subsection{Challenges MASLOC beneficiaries face in accessing micro credit facilities in the Sunyani Municipality}

Table 4.8 illustrates the responses on the challenges MASLOC beneficiaries face in accessing micro credit facilities in the Sunyani Municipality. Out of the total respondents of $112,97 \%$ of the respondents representing majority complained of high interest rate on loans as a challenge in accessing loans. Shick (2011) identified high interest rate as a key factor that people face when borrowing from microfinance institutions and results high default rate among borrowers.

Similarly, $90 \%$ of the respondents classified collateral security as one of the major challenges in accessing micro loans in the Sunyani Municipality while $10 \%$ cared little about collateral to access micro loan. This limits the net of loan coverage among businesses in Municipality. Credit conditions is also talked about as one of the challenges. The study noticed that $83 \%$ of respondents considered credit conditions to be stringent when accessing loans. Only $17 \%$ of respondents were ok with the conditions of micro credit, confirming the finding of Abiola \& Salami (2011), who also noticed that stringent credit conditions attached to borrowings is one of the factors that hinder poor people accessibility to credit facilities from microfinance institutions. 
Table 9. Challenges MASLOC Beneficiaries face in Accessing Micro Credit Facilities

\begin{tabular}{|c|c|c|c|c|}
\hline Statement & SA (\%) & $\mathbf{A}(\%)$ & D (\%) & $\operatorname{SD}(\%)$ \\
\hline High interest Rate on loans & $64(57.0)$ & $45(40.0)$ & $2(2.0)$ & $1(1.0)$ \\
\hline Lack of collateral security to secure loans & $58(52.0)$ & $43(38.0)$ & $8(7.0)$ & $3(3)$ \\
\hline Stringent credit conditions & $61(54.0)$ & $32(29.0)$ & $12(11.0)$ & $7(6.0)$ \\
\hline High administrative costs associated with processing loans & $44(39.0)$ & $42(38.0)$ & $17(15.0)$ & $9(8.0)$ \\
\hline $\begin{array}{l}\text { Biasness of MASLOC staff in providing loan outside the target } \\
\text { group (to family, friends and political sympathizers) }\end{array}$ & $33(29.0)$ & $46(41.0)$ & $21(19.0)$ & $12(11)$ \\
\hline Lack of credit history and the physical remoteness of clients & $.0)$ & 42( & 12( & $6(5.0)$ \\
\hline $\begin{array}{l}\text { Lack of education, technical, financial and management skills } \\
\text { complicated accessibility procedures }\end{array}$ & $38(34.0)$ & $44(39)$ & $20(18.0)$ & $10(9.0)$ \\
\hline Loan terms not based on capacity of beneficiary & $24(21)$ & $47(42)$ & $34(31)$ & $7(6)$ \\
\hline
\end{tabular}

Source: Field Survey, 2020. Notes: SA-Strongly Agree, A-Agree, D-Disagree, SD-Strongly Disagree

Also, from Table 9,77\% of respondents considered transaction and administrative cost charge to borrowers as a deterring factor in accessing micro loan in the Sunyani Municipality. This finding is in line with the works of Abiola \& Salami, (2011) and Nawa (2010), who all established that high interest rate and high administrative costs associated with processing small loans are the main challenges hindering poor people from accessing microcredit facilities from MFIs.

Also, it was revealed that $70 \%$ forming majority of the respondents agreed to the statement that biasness of MASLOC staff in providing loan outside the target group (to family, friends and political sympathizers) is one of the major challenges they face when accessing loans from MASLOC. This outcome was however opposed by $30 \%$ of the respondents who were in disagreement to the same statement. Olumuyiwa \& Oluwatosin, (2012) also established that providing loan outside the target group (to staff friends, relatives and the like) is one of the main challenges women face when accessing credit facilities from MASLOC.

Moreover, the study shows that $84 \%$ of the respondents representing majority are in agreement to the statement that the "lack of credit history and the physical remoteness of clients" is a major challenge facing MASLOC beneficiaries in accessing credit facilities from the scheme. This finding is in line with the work of Adjei (2010) who all established these factors as the main challenges hindering poor people from accessing microcredit facilities from MFIs.

It was also discovered that majority $(73 \%)$ of the respondents stated lack of education, technical, financial and management skills as well as misplaced loan terms ( $63 \%$ of respondents) are some of the major challenges facing MASLOC beneficiaries in accessing credit facilities from the scheme.

\subsection{Effects of MASLOC facilities on improving the standard of living of beneficiaries}

A multiple regression was conducted to test the independent variables on the dependent variable. MASLOC facilities such as microcredit, micro saving, micro insurance, and financial services which serve as the independent variables were measured against various poverty indicators to improve income levels of beneficiaries which also serve as dependent variable. The hypotheses proposed for this study were tested using the regression analysis and the results have been tabled and discussed below.

Hypothesis One

$H_{10}$ : There is no significant relationship between MASLOC credit facilities and growth in income

Table 10. Model Summary of Regression Analysis for Hypothesis 1

\begin{tabular}{|l|l|l|l|l|}
\hline Model & R & R Square & Adjusted R Square & Std. Error of the Estimate \\
\hline 1 & $.834^{\mathrm{a}}$ & .721 & .757 & .156710 \\
\hline
\end{tabular}

a. Predictors: (Constant, Micro Credit, Financial Advisory Services, Entrepreneur Training, and Micro Savings)

From Table 10, it can be seen that the $\mathrm{R}^{2}$ of 0.721 implies that $72.1 \%$ of the variation in income improvement of beneficiaries is attributed to the changes in the explanatory variables (Micro Credit, Financial Advisory Services, Entrepreneur Training, and Micro Savings).

Table 11. ANOVA for Hypothesis 1

\begin{tabular}{|l|l|l|l|l|l|l|}
\hline Model & Sum of Squares & Df & Mean Square & F & Sig. \\
\hline \multirow{5}{*}{1} & Regression & 179.858 & 2 & 89.929 & 701.277 & .000 \\
\cline { 2 - 8 } & Residual & 25.262 & 197 & .128 & & \\
\cline { 2 - 7 } & Total & 205.120 & 199 & & & \\
\hline
\end{tabular}

a. Predictors: (Constant, Micro Loans/Credit, Financial Advisory Services, Savings, Training on Bookkeeping and Micro insurance)

Again, Table 11 shows the results of the Analysis of Variance (ANOVA) statistics to establish the significance of the relationship between income of MASLOC beneficiaries and the explanatory variables (Micro Credit, 
Financial Advisory Services, Entrepreneur Training, and Micro Savings). The ANOVA regression model is significant given the level of significance of 0.000 which is below 0.05 ; therefore, the model is declared fit for estimation. Moreover, the F calculated at 5\% level of significance was 701.277 which is greater than the F critical (value $=4.89$ ). This also shows that the overall model is significant and that there is a significant relationship between MASLOC facilities and income. The study therefore rejects the null hypothesis; (there is no significant relationship between MASLOC credit facilities and growth in income) and accepts the alternate hypothesis.

Table 12. Regression Coefficients

\begin{tabular}{|l|l|l|l|l|l|l|}
\hline \multirow{2}{*}{ Model } & \multicolumn{2}{|l|}{ Unstandardized Coefficients } & Standardized Coefficients & $\mathrm{t}$ & Sig. \\
\cline { 2 - 7 } & $\mathrm{B}$ & Std. Error & Beta & & \\
\hline \multirow{2}{*}{1} & (Constant) & .712 & .083 & & 5.034 & .000 \\
& Micro Credit & .343 & .057 & .341 & 3.102 & .000 \\
& Financial Advisory Services & .476 & .133 & .304 & 2.430 & .000 \\
& Micro Savings & .672 & .132 & .221 & 2.562 & .000 \\
& Entrepreneur Training & .347 & .184 & .256 & 3.546 & .000 \\
\hline
\end{tabular}

Also, Table 12 shows the regression coefficients of independent variables that explains the changes in income. Taking all other independent variables at zero, a unit increase in Microcredit will lead to a 0.343 increase in income of MASLOC beneficiaries; unit increase in Financial Advisory Services, Micro Savings and Entrepreneur Training will lead to a $0.476,0.672$, and 0.347 increase in income of MASLOC beneficiaries, respectively. Again, it can be noticed from the model that all the values are significant. This outcome shows that all the independent variables are positively correlated with income of MASLOC beneficiaries and therefore conclude that there is a significant relationship between MASLOC credit facilities and growth in income.

\section{Hypothesis Two}

$H_{2 o}$ : There is no significant relationship between MASLOC credit facilities and increase in consumption expenditure

Table 13. Model Summary of Regression Analysis for Hypothesis 2

\begin{tabular}{|l|l|l|l|l|}
\hline Model & R & R Square & Adjusted R Square & Std. Error of the Estimate \\
\hline 1 & $.937^{\mathrm{a}}$ & .878 & .860 & .37220 \\
\hline
\end{tabular}

a. Predictors: (Constant, Micro Loans/Credit, Financial Advisory Services, Savings, Training on Bookkeeping and Micro insurance)

From Table 13, it can be seen that the $\mathrm{R}^{2}$ of 0.878 implies that $87.8 \%$ of the variations in income of beneficiaries are attributed to the changes in the explanatory variables (Micro Credit, Financial Advisory Services, Entrepreneur Training, and Micro Savings).

Table 14. ANOVA for Hypothesis 2

\begin{tabular}{|l|l|l|l|l|l|l|}
\hline \multicolumn{2}{|c|}{ Model } & Sum of Squares & Df & Mean Square & F & Sig. \\
\hline \multirow{5}{*}{1} & Regression & 143.931 & 13 & 11.072 & 196.957 & $.000^{\mathrm{b}}$ \\
\cline { 2 - 7 } & Residual & 5.059 & 101 & .056 & & \\
\cline { 2 - 7 } & Total & 148.990 & 114 & & & \\
\hline
\end{tabular}

a. Predictors: (Constant, Micro Loans/Credit, Financial Advisory Services, Savings, Training on Bookkeeping and Micro insurance) $. \mathrm{b}=$ Significant

Table 14 shows the Analysis of Variance (ANOVA) statistics which establish the significance of the relationship between increase in consumption expenditure of MASLOC beneficiaries and the explanatory variables (Micro Credit, Financial Advisory Services, Entrepreneur Training, and Micro Savings). The ANOVA regression model is significant given the level of significance 0.000 which is below 0.05 ; therefore, the model is declared fit for estimation. The F calculated at 5\% level of significance was 196.957. This shows that the overall model was significant i.e. there is a significant relationship between MASLOC facilities and increase in consumption expenditure. The study therefore rejects null hypothesis; (there is no significant relationship between MASLOC credit facilities and increase in consumption expenditure) and accept the alternate.

Table 15. Regression Coefficients

\begin{tabular}{|l|l|l|l|l|l|l|}
\hline \multicolumn{2}{|l|}{ Model } & \multicolumn{2}{l|}{$\begin{array}{l}\text { Unstandardized } \\
\text { Coefficients }\end{array}$} & $\begin{array}{l}\text { Standardized } \\
\text { Coefficients }\end{array}$ & $\mathrm{t}$ & Sig. \\
\cline { 3 - 8 } \multicolumn{2}{l|}{} & B & Std. Error & Beta & & \\
\hline \multirow{2}{*}{1} & (Constant) & .666 & .083 & & 8.054 & .000 \\
& Micro Credit & .230 & .057 & .256 & 4.008 & .000 \\
& Financial Advisory Services & .353 & .133 & .216 & 2.660 & .000 \\
& Micro Savings & .518 & .132 & .317 & 3.918 & .000 \\
& Entrepreneur Training & .209 & .050 & .223 & 4.166 & .000 \\
\hline
\end{tabular}

Also, Table 15 shows the regression coefficients of independent variables that explains the changes in increase in consumption expenditure. The data findings analyzed shows that taking all other independent variables 
at zero, a unit increase in Microcredit will lead to a 0.230 increase in consumption expenditure of MASLOC beneficiaries; unit increase in Financial Advisory Services, Micro Savings and Entrepreneur Training will lead to a $0.353,0.518$, and 0.209 increase in consumption expenditure of MASLOC beneficiaries, respectively. Again, it can be noticed from the model that all the values are significant. This outcome shows that all the independent variables are positively correlated with consumption expenditure of MASLOC beneficiaries.

4.2.5 Hypothesis Testing

The first hypothesis proposed that there is no significant relationship between MASLOC credit facilities and growth in income. The results of the regression analysis and the ANOVA show that there is a positive relationship between MASLOC facilities and growth in income. The study therefore accepts the alternate hypothesis $\left(\mathrm{H}_{1 \mathrm{a}}\right)$ and failed to accept the null hypothesis $\left(\mathrm{H}_{10}\right)$ which states that there is no significant relationship between MASLOC credit facilities and growth in income.

Secondly, the tests also proved opposite that there is statistically significant positive relationship between MASLOC facilities and increase in consumption expenditure. The study therefore failed to accept the null hypothesis $\left(\mathrm{H}_{10}\right)$ and accepted the alternate hypothesis $\left(\mathrm{H}_{1 \mathrm{a}}\right)$ that there is significant positive relationship between MASLOC facilities and increase in consumption expenditure. This finding is in line with a similar finding of Abbas (2005) who noticed that there is a positive impact of microfinance on income and consumption smoothening of poor people.

\section{Summary, Conclusions and Recommendations}

\subsection{Summary of Key Findings}

The major findings of the study have been summarized and enumerated below. On the level of poverty among beneficiaries before becoming MASLOC beneficiaries in the Sunyani Municipality;

- majority of the current beneficiaries of MASLOC were jobless and had no businesses before joining the scheme in the Sunyani Municipality.

- most of the current beneficiaries of MASLOC indicated that previously they were not able to improve the quality of their business products and services in the Sunyani Municipality.

- most of the beneficiaries of MASLOC indicated that they had difficulties in sending and pay my children school fees and other educational needs before joining MASLOC scheme.

- most beneficiaries of MASLOC indicated that they had challenges in feeding and clothing my family before joining MASLOC scheme.

- most MASLOC beneficiary indicated that before joining the scheme they were not able to save enough money to insure my family to cope with future crises.

With respect to the benefits of MASLOC to the beneficiaries in the Sunyani Municipality, the study outcome shows that;

- majority of MASLOC beneficiaries indicated that they have been able to start up and or expand my business after joining the scheme.

- most of MASLOC beneficiaries indicated that they have been able to improve the quality of my business products and service after joining the scheme

- majority of the MASLOC beneficiaries indicated that they have had an increase in their business activities which have improved their living condition.

- majority of the MASLOC beneficiaries indicated that they have been able to send and pay my children school fees and other educational needs as well as to pay for their family medical bills.

The study also identified challenges that MASLOC beneficiaries face when accessing credit facilities in the Sunyani Municipality. They include;

- majority of MASLOC beneficiaries identified high interest rate on loans.

- majority of the MASLOC beneficiaries identified lack of collateral security to secure loans

- majority of the MASLOC beneficiaries identified stringent credit conditions.

- most of the MASLOC beneficiaries identified high administrative costs associated with processing loans

- most of the MASLOC beneficiaries identified biasness of MASLOC staff in providing loan outside the target group (to family, friends and political sympathizers)

- most of the MASLOC beneficiaries identified lack of credit history and the physical remoteness of clients

- most of the MASLOC beneficiaries identified lack of education, technical, financial and management skills that complicated accessibility procedures

On the effects of MASLOC facilities on improving the standard of living of beneficiaries

- majority of the MASLOC beneficiaries agree that MASLOC facilities lead to growth in income.

- majority of the MASLOC beneficiaries agreed that they have been able to improve on their businesses which have in turn boost their income thereby causing an increased the consumption.

- majority of the MASLOC beneficiaries agreed that they have been able to acquire and expand their 
business assets.

- majority of the MASLOC beneficiaries agreed they have been able to provide better and quality healthcare for their family especially empowering them to educate their children

\subsection{Conclusion}

First of all, it can be emphatically concluded that the level of poverty among beneficiaries before becoming MASLOC beneficiaries in the Sunyani Municipality was very high which made them jobless, prevented them from improving the quality of their business products and services, made it difficult feeding and clothing their families as well as unable to afford education and provide for their other educational needs.

Secondly, it can be deduced that MASLOC beneficiaries have enjoyed some benefits from the scheme such as able to start up and or expand my business able to improve the quality of their business products and service, have been able to send and pay their children school fees and other educational needs as well as to pay for their family medical bills.

Thirdly, it can also be concluded that despite the benefit of the MASLOC scheme, beneficiaries still face challenges in accessing credit facilities. MASLOC beneficiaries face challenges such as high interest rate on loans, lack of collateral security to secure loans, stringent credit conditions, administrative costs associated with processing loans, biasness of MASLOC staff in providing loan outside the target group (to family, friends and political sympathizers), lack of credit history and lack of education, technical, financial and management skills that complicated accessibility procedures.

Finally, the study concluded that MASLOC facilities have a lot of significant effects on improving the standard of living of beneficiaries. Also, it has been proven that MASLOC facilities have helped beneficiaries to acquire and expand their business assets resulting in improvement of sales and increase in income and consumption. This has empowered them to provide their family basic needs, educate their children and increased their consumption expenditure.

\subsection{Recommendations}

The following recommendations are made.

The authorities and management of MASLOC should work in collaboration with the National Commission for Civic Education and other media organizations to develop and implement an advocacy and sensitization programme to educate the general public on the objectives of the MASLOC scheme. This can be done by hosting radio programmes and inviting beneficiaries from the Sunyani Municipality to testify about the benefits they have gained from MASLOC to draw the general public attention to the MASLOC scheme.

Secondly, the authorities and management of MASLOC should provide and create a system that makes it very easy and fair for poor people to access credit from the scheme instead of favoring family, friends and political sympathizers.

Also, the Government of Ghana (GoG) through the Bank of Ghana (BoG), Ministry of Gender and Local Government should develop and implement policies that makes it favourable for poor people to access credit facilities from MASLOC and other FIs that grant credit to poor people. This would help to mitigate the challenges facing people in accessing credit facilities in the Sunyani Municipality and Ghana as a whole. The policy should consider the interest rate on loans as well as requirement conditions people need to meet before accessing loans. Finally, further studies should be conducted on the challenges facing MASLOC on providing services to the poor in other parts of the Bono East Region and in other parts of Ghana. This can help to mitigate the challenges facing MASLOC in its operation.

\section{References}

Adjei, J. (2010), "Microfinance and Poverty Reduction: The Ghanaian Experience", Bold Communication Ltd, Accra.

Alhassan, A.R., \& Akudugu, M. A. (2012), "Impact of Microcredit on Income Generation Capacity of Women in the Tamale Metropolitan Area of Ghana", Journal of Economics and Sustainable Development, 3 (5): 41-48

Ampah, S.N., Jagongo, O.A., Omagwa, J.O. \& Frimpong S. (2017), "Effect of Access to Credit and Financial Services on Poverty Reduction in Central Region of Ghana", International Journal of Business and Social Science, 8(8), 49-60

Antwi, B. D (2015), "Microfinance and Poverty Reduction in Ghana: Evidence from the Dormaa Area Teachers Co-operative Credit Union in Dormaa Municipality-Brong Ahafo", Unpublished thesis, School of Economics and Business. Norwegian University of Life Sciences (NMBU).

Bannor, R.K and Oppong-Kyeremeh H. (2017), "Extent of Poverty and Inequality among Households in the Techiman Municipality of Brong Ahafo Region, Ghana”, ICCCSDA 2017 Special Issue: Environment, Technology and Sustainable Development, 1(1), 26-36

Hidalgo, B., \& Goodman, M. (2013), "Multivariate or multivariable regression?" American journal of public 
health, 103(1), 39-40. https://doi.org/10.2105/AJPH.2012.300897

Canagarajah, Sudharshan \& Chr, Claus. (2003), "Evolution of Poverty and Welfare in Ghana in the 1990s: Achievements and Challenges", The World Bank.

CGAP. (2002), "Helping to Improve Donor Effectiveness in Microfinance", MICROCREDIT: One of the many Intervention Strategies.

Chirkos, A.Y. (2014), "The Role of Microfinance Institutions in the Development of Small and Medium Size Businesses in Ethiopia: A Case Study in Amhara Credit and Saving Institutions", Research Journal of Finance and Accounting, 5, 102-117.

Debrah, E. (2013), "Alleviating Poverty in Ghana: The Case of Livelihood Empowerment against Poverty (LEAP)", Africa Today, 59(4), 40-67

Dzisi, S., \& Obeng, F. (2013), "Microfinance and the Socio-Economic Wellbeing of Women Entrepreneurs in Ghana. International Journal of Business and Social Research (IJBSR), 3 (11), November, 2013

Garikipati, S. (2017), "The Impact of Microfinance on Poverty Alleviation: Making Sense of the Evidence" Development Finance (pp.189-206), 10.1057/978-1-137-58032-0_7.

Ghana Statistical Service (2013), "2010 Population and Housing Census: Non-Monetary Poverty in Ghana", Ghana Statistical Service, Accra.

Ghana Statistical Service (2015), “Ghana Poverty Mapping Report”, Poverty Map for Ghana, May, 2015, pp.2728

Idowu A., and Salami, A.O., (2011), "Impact of Microfinance Bank on Standard of Living of Hairdresser in Ogbomoso North Local Government of Oyo State, Nigeria", International Business Management, 5: 27-32.

Imtiaz, A., Mehmood, H. Z., Akram, W., \& Irfan, M. (2014), "Impact of Microfinance on Poverty Reduction: A Case Study of District Faisalabad", Journal of Economics and Sustainable Development. Vol. 5, No. 9. https://www.iiste.org/Journals/index.php/JEDS/article/view/13214

Jaha, I.R. and Sika-Bright, S. (2015), "Challenges of the Livelihood Empowerment against Poverty Programme in the Upper West Region of Ghana: the Institutional Perspective", UDS International Journal of Development [UDSIJD], 2(1), 190-99

Kasali, T., Ahmad, S., Eam, Lim. (2015). The Role of Microfinance in Poverty Alleviation: Empirical Evidence from South-West Nigeria. Asian Social Science. 11. 10.5539/ass.v11n21p183.

Kyale, M.S. (2013), "Impact of Microfinance Institutions on Growth and Development of SMEs in Machakos Town", Unpublished PhD thesis, university of Nairobi

Microfinance and Small Loans Centre (2011) Operational Guidelines.

Microfinance and Small Loans Centre (2018) Customer Data, Sunyani Centre

Microfinance and Small Loans Centre Programme (2010) Ghana 2010-2018 International Monetary Fund Country Report no. 03186, 2003

Mwinga, M. (2012). "Unemployment in Namibia: measurement problems, causes and policies", Windhoek: First Capital Research. 23-31

Nyakambi, A.G. (2014), "Effect of microfinance credit on poverty alleviation at household level in Nakuru County", Unpublished MBA project, university of Nairobi

Obeng C.K. (2011), "The impact of micro-credit on poverty reduction in rural areas-a case study of Jaman North District, Ghana", Unpublished MBA project, University of Ghana

Obwanga, S.O. (2012), "Impact of SACCOs in alleviation of poverty in Kenya", Unpublished MBA project, University of Nairobi

Oduro-Ofori, E., Anokye P.A. \& Edetor, M. (2014), "Microfinance and Small Loans Centre (MASLOC) as a Model for Promoting Micro and Small Enterprises (MSEs) in the Ashaiman Municipality of Ghana", Journal of Economics and Sustainable Development, 5(8), 53-65

Okibo, B.W. \& Makanga, N. (2014), "Effects of micro finance institutions on poverty reduction in Kenya", International Journal of current research and Academic Review, 2(2), 76-95

Olusanya, S. (2012), "Impact of Microfinance Bank on Standard Of Living of Hairdresser in Oshodi-Isolo Local Government of Lagos State", IOSR Journal of Humanities and Social Science. 1. 26-35. 10.9790/08370142635.

Quansah, P., Amankwah, E., \& Aikins, E. (2012), "Influence of Micro Finance and Small Loan Centre (MASLOC) on the Development of Small Scale Enterprises in the Wa Municipality", European Journal of Business and Management, 4(1), 1-11

Qureshi, M. I., Saleem, M. A., Khan, G. U., \& Ali, M. I. (2012), “A Conceptual Framework: Role \& Impact Relationship between Micro Finance and Poor's Access: A case study of D. I. Khan District Khyber Pakhtunkhwa", Pakistan Introduction: 717-732

Rajper, Z., Ghumro, I., Mangi, R. \& Lund, J. (2018), “Assessing the Role of Micro Finance for Poverty Alleviation in Sindh", SALU-Commerce \& Economics Review, Volume 4. 105-113.

Visconti, E. (2012), "A Survey on Microfinance for Developing Countries", A Social Responsible Investment 
Opportunity, April 10, 2012

World Bank (2011), "Country Brief: Ghana", Washington, DC: World Bank

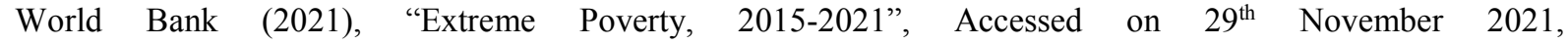
https://www.worldbank.org/en/topic/poverty

Yaro, J. A. (ed). (2013), "Rural Development in Northern Ghana", New York: Nova Science Publishers 